\title{
Upper Volta
}

Mr. Thiombianon Idrissa, Vice-President of the Upper Volta Red Cross, having kindly drawn the ICRC's attention to the interesting article he published in Carrefour africain (Ouagadougou, April 1966) on the work of the National Society's General Assembly, we now have pleasure in producing this text which describes the work being carried out in Upper Volta under our same emblem.

One hundred and five delegates from 41 local Red Cross committees and sub-committees, and ten observers from seven localities not yet possessing Red Cross Committees, met at Ouagadougou from 6 to 8 April 1966 with a view to discussing all questions relating to the work programme of the Upper Volta Red Cross Society. The deliberations took place in the "Maison du Peuple".

Three plenary sessions and three meetings of commissions enabled the various participants to complete the agenda proposed to them by the Central Committee of the Upper Volta Red Cross. Five commissions were constituted as follows :

1. Organization, Training and Relief.

2. Finance.

3. First-aid.

4. Blood Bank.

5. Junior Red Cross.

Each commission had to study a general report and adopt resolutions and recommendations which were discussed by the General Assembly in plenary session. Their main points were as follows.

As regards Organization, that Commission, taking into account the results achieved over five years of operation, proposed amendments to the Statutes of the Upper Volta Red Cross. These amendments concerned the composition of the National Society and its financial resources (participation of regional committees and con- 
tributions in particular). The Commission requested the Central Committee to make known to the Government the contents of the resolutions adopted at the XXth International Conference of the Red Cross. Two further resolutions thanked the international bodies of the Red Cross, sister Red Cross Societies, the public authorities and private Red Cross undertakings for their assistance in the development of the Upper Volta Red Cross.

The Finance Commission drew up a budget and submitted draft model estimates for committees and sub-committees to adopt with a view to co-ordinating all financial transacting. This was agreed in principle by the assembly, as well as the setting up of a finance commission in accordance with the statutes.

The First-Aid Commission proposed a new structure in order to improve the efficiency of first-aiders, special mention being made of the need of close co-operation between the Red Cross and the armed forces. The creation of a National First-aid committee at government level was much appreciated by the various participants. Finally, the General Assembly requested the national committee to draw up a plan of action with a view to extending firstaid training courses throughout the country which would be incorporated in active teams.

The Blood Bank Commission dealt with problems touching on the establishment of a Blood Bank (premises, collections and training). The conclusions of the Commission's work were approved by the General Assembly which also requested that the Blood Bank be represented at the various international blood transfusion bodies at which contacts are fruitful in the field of technical knowledge and the equipping of transfusion centres.

The Junior Red Cross Commission submitted an account of the work and organization of the Junior Red Cross. It requested that modifications be made in the composition of the National Council. The meeting every three months of the regional heads of the JRC was approved. The programme of school and international exchanges was also agreed. The National Committee of the Junior Red 


\section{IN THE RED CROSS WORLD}

Cross received the mandate to transmit all desirable information to each administrative district for the purpose of setting up a wider network of junior groups.

In the afternoon of April 7 the participants motored through the streets of the capital and were applauded by the crowd, especially in the market-place.

On April 8 a morning session, at which free views were exchanged between delegations, enabled local problems to be discussed and questions raised on the preoccupations of the Red Cross in the world today and more especially in Upper Volta. The discussion was closely followed by the delegates and also by the observers present who were thus able to learn of the difficulties they might have to encounter during the course of their mission.

After the session was closed by the representative of the Minister of Public Health, the heads of delegations received bundles of clothing and educational material for their committees and subcommittees.

During the time that the General Assembly was in session a Red Cross exhibition was held demonstrating the various spheres in which the Red Cross intervenes in the world (first-aid in disasters, the fight against hunger, intervention in armed conflict, Junior Red Cross etc.). Illustrations of Red Cross events in Upper Volta, presentation of equipment (stretchers, projectors, first-aid kits ...) were of keen interest to our visitors and made them realize that our work, even if it is uncompleted, is however making great progress.

Cinema performances for the benefit of the Red Cross took place on April 6 and 7 in the town's two cinemas. The public contributed generously and has enabled the Volta Red Cross to make further progress.

For many delegates, this meeting was necessary. The next General Assembly will take place in the last quarter of 1967. It will be carefully prepared and there is no doubt that it will be as successful as this first session has been.

To all those who participated in the success of its meetings, to those who followed the progress of its work, the Upper Volta Red Cross expresses its gratitude and invites the whole population to place itself at the disposal of the committees and sub-committees 
by every possible means, either by joining the Red Cross, encouraging the young to belong to Junior groups, by helping in first-aid training or by giving advice of all kinds.

We would finally recall that the first General Assembly of the Upper Volta Red Cross was held under the sign of the fundamental Red Cross principles. These were read at the official opening ceremony by the Secretary-General of the National Society before the standing audience. 